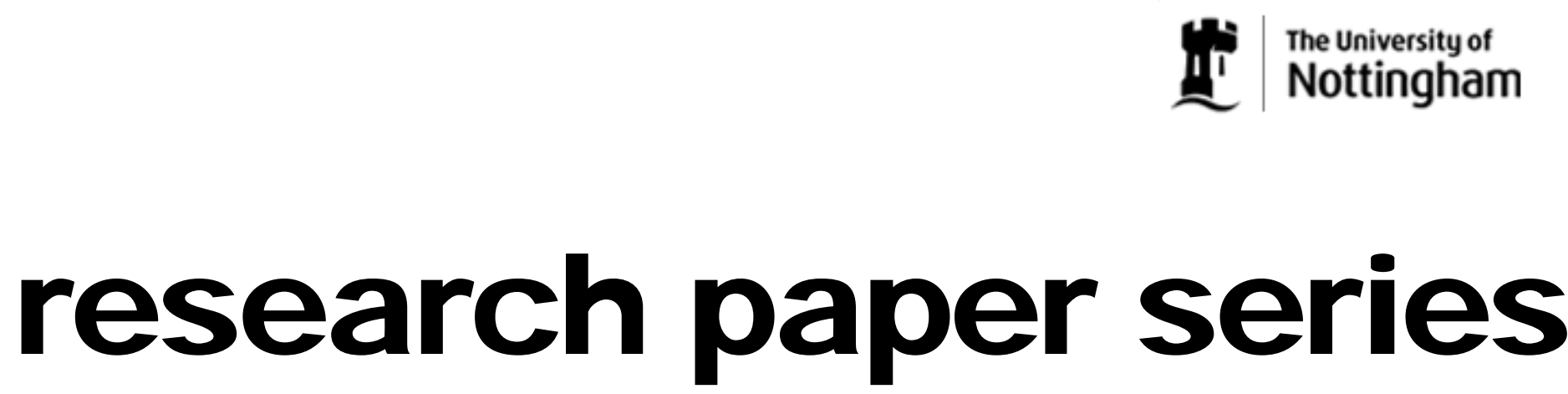

Theory and Methods

Research Paper 2007/17

How Bad is Antidumping?: Evidence from Panel Data

by

Peter Egger and Douglas Nelson

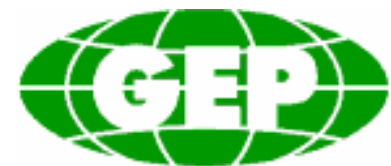




\section{The Authors}

Peter Egger is Professor of Economics at the Ludwig-Maximilian University of Munich, Ifo member, and External Research Fellow of the Leverhulme Centre for Research on Globalisation and Economic Policy. Douglas Nelson is a Professorial Research Fellow in GEP and Professor of Economics at Tulane University.

\section{Acknowledgements}

The authors are grateful to the Leverhulme Centre for Research on Globalisation and Economic Policy at the University of Nottingham for providing support during the writing of this paper. The primary data set was made available by Chad Bown. In addition, we have had help on data from Peter Lloyd, Patrick Messerlin, and Maurizio Zanardi. The authors want to thank Tobias Seidel for excellent assistance with data collection. Peter Egger acknowledges funding from the Austrian Science Fund through grant P17713-G05. 


\title{
How Bad is Antidumping?: Evidence from Panel Data
}

\author{
by
}

\author{
Peter Egger and Douglas Nelson
}

\begin{abstract}
Current research on antidumping suggests a number of channels through which antidumping affects the volume of world trade. This paper uses a structural approach to the gravity model framework to evaluate these hypotheses using data on trade volume over the period 1960-2001. We conclude that the volume and welfare effects have been negative, but quite modest.
\end{abstract}

JEL classification: C230; F14; F15

Keywords: Antidumping; Gravity equation; Multilateral resistance; Panel data econometrics

\section{Outline}

1. Introduction

2. The link between antidumping and trade volume

3. An empirical gravity model for panel data

4. Data description

5. Panel data estimates of the impact of antidumping investigations on trade volumes

6. Welfare effects of antidumping

7. Conclusions 


\section{Non-Technical Summary}

As with the wave of interest in the "new protection" in the 1970s, we are now observing a new wave of concern with a rapid increase in the use of "non-traditional" protectionist instruments. Once again, the main culprit is contingent protection (primarily antidumping and countervailing duties, though voluntary export restraints---mainly coming from the safeguards process---also figured prominently in the 1970s). These forms of protection are "contingent" because they are dependent on a quasi-judicial/bureaucratic finding prior to application of the protection. By contrast, traditional protection is "statutory", i.e. it is applied in every case, without any such finding. This is a more useful distinction than the common "tariff v. nontariff barrier" distinction since contingent protection is usually included in the latter even though it is implemented by tariffs. The main difference is that in the 1970s the main users were industrial countries (mainly the US, EU, Canada, and Australia), the millennial new users, and the main source of growth in use, are developing countries and countries in transition (Argentina, Brazil, Mexico, South Korea, Taiwan, Turkey). In this paper, we are primarily concerned with the aggregate impact of the spread of antidumping on trade.

From the extensive literature on antidumping, we identify four channels through which the use of antidumping might affect the aggregate trade of a nation. These derive from: standard protection effects; from the fact that this protection is non-MFN in nature; from the fact that it is contingent protection; and from the fact that it is firm-specific. These channels imply different hypotheses about the aggregate effects of antidumping which can then be empirically evaluated.

Our empirical analysis is based on the gravity model framework which has become a standard tool in establishing an empirical baseline for the analysis of equilibrium trade patterns and deviations therefrom. Such a baseline needs, in principle, to reflect the underlying general equilibrium of the world trading system. With the development of theoretical foundations for the gravity model, along with its statistical success in accounting for trade patterns, the gravity model has increasingly become the econometric framework of choice when seeking to analyze deviations from expected trade between two countries

Overall, our analysis suggests that the aggregate effects of $A D$ in the context of the GATT/WTO system are modest. This should not be taken to imply that $A D$ is not, or should not be, a matter of concern to the Liberal international trading system. Given the magnitude of duties, the sectoral distortions can be quite sizable. In addition, the control of protection and the advance of liberalization are the centerpieces of that system and $A D$ protection is protection. At the same time, it does not seem useful to oversell the consequences of $A D$. Since it seems likely that contingent protection has played an important role in supporting trade liberalization, reflexive rejection seems particularly inappropriate. 


\section{Introduction}

As with the wave of interest in the "new protection" in the 1970s, we are now observing a new wave of concern with a rapid increase in the use of "non-traditional" protectionist instruments (e.g. Prusa, 2001; Zanardi, 2006). Once again, the main culprit is contingent protection (primarily antidumping and countervailing duties, though voluntary export restraints - mainly coming from the safeguards process - also figured prominently in the 1970s). ${ }^{1}$ The main difference is that in the 1970 s the main users were industrial countries (mainly the US, EU, Canada, and Australia), the millennial new users, and the main source of growth in use, are developing countries and countries in transition (Argentina, Brazil, Mexico, South Korea, Taiwan, Turkey). ${ }^{2}$ In this paper, we are primarily concerned with the impact of the spread of antidumping on trade.

Before turning to a discussion of the main issues, we can fix the essential facts with two figures drawn from Zanardi (2006). Figure 1 shows the strong upward trend in investigations and Figure 2 shows a more modest growth in the number of antidumping orders in place. What both figures make clear, however, is that while there may be some downward trend in use of contingent protection by traditional users, the trend in new users is strongly upward. Additional data presented in Zanardi (2006, Tables 1, 2, and 5) show that the new users are drawn from nearly the full range of WTO members (the exception being small, poor countries). This suggests the potential for very wide adoption and use of these mechanisms. While the spread of contingent protection mechanisms, and their use, is an undeniable fact, the scale of their use and the welfare effects are considerably less certain. The public rhetoric, as well as that in much of the academic research on antidumping, could easily give the impression that these effects are sizable. In this paper we develop a framework within which we can evaluate most of the common hypotheses

\footnotetext{
${ }^{1}$ These forms of protection are "contingent" because they are dependent on a quasijudicial/bureaucratic finding prior to application of the protection. By contrast, traditional protection is "statutory", i.e. it is applied in every case, without any such finding. This is a more useful distinction than the common "tariff v. nontariff barrier" distinction since contingent protection is usually included in the latter even though it is implemented by tariffs.

${ }^{2}$ Note that the industrial countries continue to be quantitatively the biggest users, but growth in use is coming from developing countries.
} 
relating to the aggregate effects of antidumping.

Our analysis will be based on the gravity model framework which has become a standard tool in establishing an empirical baseline for the analysis of equilibrium trade patterns and deviations therefrom (Feenstra, 2004). Such a baseline needs, in principle, to reflect the underlying general equilibrium of the world trading system. Early attempts to identify deviations generated by the presence of various forms of protection sought to use the structure provided by the Heckscher-Ohlin model but did not appear to produce convincing results (e.g. Leamer, 1987; 1990). With the development of theoretical foundations for the gravity model, along with its statistical success in accounting for trade patterns, the gravity model has increasingly become the econometric framework of choice when seeking to analyze deviations from expected trade between two countries. ${ }^{3}$ More recently, the gravity model has also been used to evaluate the effect of fundamental institutions such as the WTO and various forms of preferential trade and currency arrangement. ${ }^{4}$ In the next section we develop the motivation for our analysis of the link between antidumping and trade volume, followed by a presentation of our theoretical and econometric framework. Then we present our empirical results and robustness in the following sections.

\section{The link between antidumping and trade volume}

The literature on the economics and political economy of antidumping (henceforth "AD") is large, but we can identify four classes of channel through which AD affects trade

\footnotetext{
${ }^{3}$ The key papers providing theoretical foundations for the gravity model are: Anderson (1979), Bergstrand (1985; 1989), and Deardorff (1998). The industry standard, on which we also rely, is Anderson and VanWincoop (2003). Wall (1999) provides a useful discussion of the gravity model as a framework for evaluating the effect of protection on trade.

${ }^{4}$ For instance, Rose (2004a; 2004b) finds that membership in the WTO has no systematic effect on trade pattern, while Subramanian and Wei (forth.) finds that WTO membership exerts a powerful and positive impact on trade for a subset of countries that adopt liberalizing policies as part of accession to the WTO. Baldwin (1994), Frankel (1997), and Baier and Bergstrand (forthcoming) use the gravity model to examine the trade effects of regional trading blocs, while the results in Frankel and Rose (2002), Rose (2000), and Rose and VanWincoop (2001) point to the relevance of (various forms of) currency arrangements on trade volume.
} 
volumes: ${ }^{5}$ direct protection effects; effects due to the contingent nature of protection; effects due to the non-MFN nature of protection; and effects due to the firm-specific nature of protection. We consider each in turn.

Direct effects of protection recognize that $\mathrm{AD}$ tariffs are protection, and protection reduces trade volumes and welfare. As with all other forms of protection, there are a variety of strong cases to be made against protection as a policy instrument for most uses. In particular, protection distorts incentives leading to suboptimal use of scarce national resources. Especially in the context of very low statutory rates of protection, the often very high rates of contingent protection can imply substantial distortion. These effects should cause reduced trade between the country imposing the duty and the exporter to that country's market. However, the measured aggregate effects are rather low. Rough and ready analyses for the case of the US suggest that the welfare cost of AD may be as low as \$2-4 billion for the US in 1993 (Gallaway, Blonigen and Flynn, 1999). ${ }^{6}$ This is hardly surprising since the amount of trade directly affected by contingent protection is quite small-less than $5 \%$ of trade flows. ${ }^{7}$

A related direct effect has to do with retaliation. Following research on retaliation in general models of protection, recent research has suggested that the trade volume effects (and welfare effects) of protection could be worse if the trading partner retaliates (Prusa and Skeath, 2002). On the other hand, as Blonigen and Bown (2003) argue, protection may be less likely in a dyad where both parties possess an $\mathrm{AD}$ mechanism. In the latter case, then, the spread of $\mathrm{AD}$ would be trade increasing.

Beyond the standard problems with protection, there are three additional classes of issue more-or-less unique to $\mathrm{AD}$ : one directly related to its contingent nature; a second related to its non-MFN nature; and a third related to its firm-specific nature. Because

\footnotetext{
${ }^{5}$ For surveys of the work on antidumping see: Blonigen and Prusa (2003), Falvey and Nelson (2006), and Nelson (2006).

${ }^{6}$ According to the 2006 Economic Report of the President, in 1993 the US GDP was $\$ 6.7$ trillion.

${ }^{7}$ There are other sources of cost, most prominently rent-seeking and dynamic effects, but these are unlikely to affect the trade volumes that are the empirical focus of this paper. For example, for the US, the costs of filing cases are moderate and, at least over the sample period of this paper, revenues from antidumping went into general revenue and weren't seekable as such. This changed with the adoption of the Byrd amendment in 2000.
} 
contingent protection is contingent on an administrative decision, it is in its nature uncertain. A firm currently facing statutory protection would presumably prefer a positive probability of the fixed level of protection to that fixed level of protection with certainty, but given the support of tariffs that the $\mathrm{AD}$ authorities draw from, they may well be averse to a more general AD duty lottery. Furthermore, firms that are not exposed to a statutory tariff will be unambiguously negatively affected by exposure to AD risk. There is considerable anecdotal evidence that foreign firms do, in fact, price in such a way as to avoid AD risk (though, for obvious reasons, there is essentially no systematic evidence on the extent of this practice). Nonetheless, it is perfectly plausible that protection against one line of goods from a given exporter, $i$, could have effects on exports of other goods from $i$, the same line of goods from other countries, and even producers of other goods from other countries. The breadth of this effect leads Vandenbussche and Zanardi (2006) to refer to this as the "global chilling effect" of $\mathrm{AD}$.

A third source of concern is that $\mathrm{AD}$ protection, because it responds to exports from specific countries, violates the fundamental GATT/WTO commitment to nondiscrimination via the most favored nation (MFN) clause in article 1 of the GATT agreement. As an empirical matter, the problem of non-MFN protection is that the overall effects are ambiguous. Even if we presume that the net effect of an AD duty on total imports from the home country of firms named in the $\mathrm{AD}$ complaint is negative (as seems plausible, but which we can test for), the effect on exports from non-named firms, and especially firms from non-named countries, is not at all clear. On the one hand, recent work by Prusa (2001) finds that, in addition to suppressing imports from named countries, AD protection seems to increase imports from non-named countries (this would be the equivalent of "trade diversion"). In addition, Bown and Crowley (2006a; 2006b) also find "trade deflection" (restricted exporters increase their exports to unrestricted third markets). On the other hand, where Bown and Crowley focus on the effects of $\mathrm{AD}$ duties on the export behavior of firms from a single country (Japan), Prusa (2001) and Vandenbussche and Zanardi (2006) argue that, for essentially the reasons outlined above, the active use of $\mathrm{AD}$ is expected to generally reduce imports. 
Finally, as we have noted already, AD is firm-specific protection. Filing an AD complaint has positive costs, so we must presume that the expected gain from such a filing is positive. These gains may flow directly from filing or from the expected grant of protection. An enormous literature has sought to explicate and empirically identify these gains. ${ }^{8}$ For home firms, the benefits of filing come in the form of either harassment or, in a strategic context, signalling or raising rivals' costs. ${ }^{9}$ Similarly, the benefits of a positive expectation of an $\mathrm{AD}$ duty flow from either standard distributional effects of protection, rent-shifting, or supporting collusion a la Krishna's (1989) trade restrictions as facilitating devices. Given the number of potential strategic variables and market structures, it is probably not surprising that virtually any outcome is possible here. While there is some, usually rather indirect, evidence that such collusion may be present, identifying magnitudes (or even direction of effect) has proved virtually impossible. ${ }^{10}$

In the next section we develop our empirical framework. Following that we will suggest

\footnotetext{
${ }^{8}$ Much contemporary research, both theoretical and empirical, has focused on the strategic elements of administered protection, concluding that the costs of administered protection are probably far in excess of those implied by simply looking at amounts of trade covered by dumping orders and levels of protection in those lines. Surveys of this work can be found in Blonigen and Prusa (2003) and Nelson (2006).

${ }^{9}$ There is some evidence of a harassment motivation - though the most sophisticated attempt to identify such a motivation found only a very small number of cases of this sort (Staiger and Wolak, 1994, 1996).

One channel through which the presence of a contingent protection mechanism affects outcomes, even if we do not observe cases filed, is that firms may alter their strategic behavior to take into account the possibility of filing a case. Because such behavior distorts the allocation of resources, it has been called indirect rent-seeking (Leidy, 1994). For example, foreign firms may compete less aggressively so as to avoid an antidumping complaint. In addition to changing the terms of non-cooperative interaction between home and foreign firms, it is also quite possible that the presence of contingent protection may support collusion among home and foreign firms where, once again, we need not observe contingent protection in equilibrium.

${ }^{10}$ While this work is clever and suggests a warning that standard measures of cost of protection may be substantial underestimates of those costs, it is important to recognize that there is virtually no compelling empirical work here. In fact, there is a somewhat awkward tension between this conclusion and the work, from an anti-trust perspective, which suggests that most cases could not pass a first-stage JoskowKlevorik predation test (Shin, 1998). That is, most cases do not seem to involve the kind of market structure that would permit anti-trust action. It is possible that it is the cases not filed (i.e. cases in which the presence of the threat of an antidumping case supports collusion) really do yield high costs, but this seems improbable. It is ironic that, in a literature that stresses the disconnect between norms in anti-trust and norms in contingent protection, the implicit presumption among antidumping scholars is the Harvard presumption (i.e. that markets are presumed imperfectly competitive - mainly because this raises the costs of antidumping), rather than the Chicago presumption (i.e. that the market is presumed competitive).
} 
how each of the above effects can be identified within that framework.

\section{$3 \quad$ An empirical gravity model for panel data}

We consider an $N$ country world where each country has a representative consumer whose preferences are given by a constant-elasticity-of-substitution (CES) utility function reflecting a love of variety (see Dixit and Stiglitz, 1977; Krugman, 1979). ${ }^{11}$ That is, the utility of a representative consumer in country $j$ is given by

$$
u_{j}=\left[\sum_{i=1}^{N}\left(\beta_{i} c_{i j}\right)^{\frac{\sigma-1}{\sigma}}\right]^{\frac{\sigma}{\sigma-1}}, \quad i, j=1, \ldots, N
$$

where $\sigma$ is the elasticity of substitution, $c_{i j}$ is the consumption by consumers in $j$ of a single product originating in $i$, and $\beta_{i}$ is a distribution parameter that is inversely related to country $i$ 's fraction of world endowments. The budget constraint of consumers in $j$ may be written as

$$
Y_{j}=\sum_{i=1}^{N} p_{i} t_{i j} c_{i j}
$$

where $Y_{j}$ is country $j$ 's income (GDP), $p_{i}$ is the mill price of differentiated products in $i$, and $t_{i j} \geq 1$ is a trade cost index such that $t_{i j}-1$ is the fraction of consumer prices that accrues to (tariff and non-tariff) trade costs. Maximizing (1) subject to (2) determines aggregate demand of consumers in $j$ for goods from $i$ at market prices as

$$
X_{i j}=Y_{j}\left(\frac{p_{i} t_{i j}}{P_{j}}\right)^{1-\sigma},
$$

\footnotetext{
${ }^{11}$ In contrast to Dixit and Stiglitz (1977) and Krugman (1979) we model countries here as endowment economies as in Anderson and VanWincoop (2003). Hence, we do not introduce separate variables for the number of firms in each economy, but we use the distribution parameter $\beta_{i}$ to indicate a country's mass in world supply.
} 
where the aggregate price of the consumption bundle of consumers in $j$ under CES preferences $\left(P_{j}\right)$ is determined as

$$
P_{j}=\left[\sum_{i=1}^{N}\left(\beta_{i} p_{i} t_{i j}\right)^{1-\sigma}\right]^{\frac{1}{1-\sigma}}
$$

In an important recent contribution, Anderson and VanWincoop (2003) illustrate how the condition of goods market clearing reflected in $Y_{j}=\sum_{i=1}^{N} p_{i} t_{i j} c_{i j}=\sum_{i=1}^{N} X_{i j}$ together with that of symmetric trade frictions $t_{i j}=t_{j i}$ may be used to reformulate (3) as

$$
X_{i j}=\frac{Y_{i} Y_{j}}{Y_{W}}\left(\frac{t_{i j}}{P_{i} P_{j}}\right)^{1-\sigma}
$$

where $Y_{W} \equiv \sum_{i=1}^{N} Y_{i}=\sum_{j=1}^{N} Y_{j}$ is world income.

Similarly, defining $\theta_{i} \equiv Y_{i} / Y_{W}$ and $\theta_{j} \equiv Y_{j} / Y_{W}$, expressions for price indices $P_{i}, P_{j}$ that obey goods market clearing can be found as

$$
P_{i}=\left[\sum_{j=1}^{N} \theta_{j}\left(\frac{t_{i j}}{P_{j}}\right)^{1-\sigma}\right]^{\frac{1}{1-\sigma}}, \quad P_{j}=\left[\sum_{i=1}^{N} \theta_{i}\left(\frac{t_{i j}}{P_{i}}\right)^{1-\sigma}\right]^{\frac{1}{1-\sigma}} .
$$

Since the price index functions in (6) are non-linear in both trade frictions and the parameters, Anderson and VanWincoop (2003) derive a non-linear estimation procedure that obtains estimates of the impact of trade frictions on trade volumes. ${ }^{12}$ Recently, Baier and Bergstrand (2006) suggest using a log-linear first-order Taylor series approximation of Anderson and VanWincoop's (2003) model. An advantage of the latter approach is its computational simplicity and its performance which has been shown to obtain parameter estimates that are very close to the ones relying on the non-linear procedure.

\footnotetext{
${ }^{12}$ Their focus is on the border effect for trade across US states and Canadian provinces relative to intra-national trade among these regions. However, the argument naturally extends to estimating the impact of trade frictions on trade volumes in such a model in general.
} 
Baier and Bergstrand rewrite the price index terms in (6) as

$$
e^{(1-\sigma) \ln P_{i}}=\sum_{j=1}^{N} e^{\theta_{j}+(1-\sigma) \ln t_{i j}-(1-\sigma) \ln P_{j}}, \quad e^{(1-\sigma) \ln P_{j}}=\sum_{i=1}^{N} e^{\theta_{i}+(1-\sigma) \ln t_{i j}-(1-\sigma) \ln P_{i}}
$$

and then apply a first-order log-linear Taylor-series expansion centered at the symmetric, non-zero trade cost equilibrium with cross-section data, $t_{i j}=t \neq 1$ and $P_{i}=P=t^{\frac{1}{2}} \neq 1$. $^{13}$ This yields the following approximate log inverse price index expressions corresponding to (7) for a symmetric world with trade frictions

$$
\begin{aligned}
-\ln P_{i}^{1-\sigma} & =(\sigma-1)\left[\frac{1}{N} \sum_{j=1}^{N} \ln t_{i j}-\frac{1}{2} \frac{1}{N^{2}} \sum_{i=1}^{N} \sum_{j=1}^{N} \ln t_{i j}\right], \\
-\ln P_{j}^{1-\sigma} & =(\sigma-1)\left[\frac{1}{N} \sum_{j=1}^{N} \ln t_{j i}-\frac{1}{2} \frac{1}{N^{2}} \sum_{i=1}^{N} \sum_{j=1}^{N} \ln t_{j i}\right] .
\end{aligned}
$$

The first-order Taylor-series approximation to the gravity model, evaluated at symmetric but non-zero trade frictions, for bilateral panel data in logs then reads

$$
\begin{aligned}
\ln X_{i j t} & =\ln Y_{i t}+\ln Y_{j t}-\ln Y_{W, t}-(\sigma-1) \ln t_{i j t} \\
& +(\sigma-1)\left[\frac{1}{N} \sum_{j=1}^{N} \ln t_{i j t}-\frac{1}{2} \frac{1}{N^{2}} \sum_{i=1}^{N} \sum_{j=1}^{N} \ln t_{i j t}\right] \\
& +(\sigma-1)\left[\frac{1}{N} \sum_{i=1}^{N} \ln t_{j i t}-\frac{1}{2} \frac{1}{N^{2}} \sum_{i=1}^{N} \sum_{j=1}^{N} \ln t_{j i t}\right] .
\end{aligned}
$$

Note that we have only outlined the deterministic part of the model in the above analysis. We follow the majority of previous work on the estimation of bilateral trade flow models by assuming that the stochastic part is linearly separable in a specification in logs as in (9). ${ }^{14}$ With panel data, the stochastic part of the model (let us refer to it as $u_{i j t}$ ) distinguishes between two components: one that is constant across periods (the between country-pairs dimension of the data) and the remaining part (the within country-pairs dimension of the

\footnotetext{
${ }^{13}$ They provide an alternative linearization at the zero-trade-cost equilibrium $t_{i j}=t=1$ and $P_{i}=P=$ 1. However, the latter seems less plausible from an empirical point of view.

${ }^{14}$ See Santos Silva and Tenreyro (2006) for an exception.
} 
data-Glick and Rose (2002) refer to the latter as the time-series dimension). In formal accounts, the overall stochastic component for country-pair $i j$ and year $t$ may be written as

$$
u_{i j t}=\mu_{i j}+\nu_{i j t}
$$

Clearly, $\mu_{i j}$ is the time-invariant part of the error term, while $\nu_{i j t}$ is an idiosyncratic disturbance term. There are two main options for modeling $\mu_{i j}$. First, assuming a specific functional form $\mu_{i j}$ could be modeled as random. However, for this to obtain consistent model parameter estimates all observables included in the model have to be independent not only of $\nu_{i j t}$ but also of $\mu_{i j}$. Otherwise, the parameter estimates are biased and inconsistent. Second, one can estimate the parameter $\mu_{i j}$ for each country-pair $i j$. Obviously this is less efficient than assuming $\mu_{i j}$ as random. Implicitly, it means that we have to estimate not only a single constant for the model but one for each country-pair. Since the number of country-pairs is much larger than the available time periods in typical gravity models, the parameters $\mu_{i j}$ will be highly inaccurate. However, usually we are not interested in the estimates of $\mu_{i j}$ but rather in the parameters of the covariates in the model. While their parameters will also be less accurate than in a model where $\mu_{i j}$ is random, the fixed country-pair effects estimator is immune to the problem of possible correlation between the covariates and the $\mu_{i j}$. Therefore, the model with a fixed $\mu_{i j}$ is a benchmark case and the one with a random $\mu_{i j}$ needs to obtain parameter estimates for the covariates that are very similar to the fixed $\mu_{i j}$ estimator. Hence, the reliability of the random country-pair effects model is testable (see Hausman, 1978) and with bilateral trade volume data it is typically significantly rejected against its fixed country-pair effects counterpart (see Glick and Rose, 2002; Cheng and Wall, 2005). While this might be seen as a problem of panel data, in fact it only raises serious concerns about parameters in cross-section models. The random country-pair effects estimator can be shown to be a weighted average of the fixed country-pair effects model and a time-averaged cross-section model (see Baltagi, 2005). Under the outlined assumptions, rejection of the random effects model due to correlation between the covariates and the $\mu_{i j}$ implies that the cross-section 
estimates are biased and inconsistent. Since previous evidence on gravity models points in that direction, we focus on panel econometric fixed effects estimates throughout.

While ours is not the first attempt to apply such techniques in the context of gravity models, their introduction in the literature on the quantification of trade volume response to trade policy is novel to the best of our knowledge. ${ }^{15}$

\section{Data description}

While the model of Anderson and VanWincoop (2003), and Baier and Bergstrand's (2006) approximation thereof, can be used for a gravity model-based quantification of the trade friction impact on trade volumes in general, previous work focused on the estimation of border effects. ${ }^{16}$ By way of contrast, our goal is to analyze the bilateral and multilateral responses of trade volumes to trade impediments in general and to $\mathrm{AD}$ investigations in particular.

\subsection{Trade volumes and GDP}

We use bilateral export volumes $\left(X_{i j t}\right)$ and exporter as well as importer GDPs $\left(Y_{i t}, Y_{j t}\right)$ as published by the International Monetary Fund (IMF). The corresponding figures are expressed in nominal U.S. dollars and span the period from 1960 to 2002 at the annual level. Bilateral export data are based on the Direction of Trade statistics and GDP is available from the International Financial Statistics.

\subsection{Geographical and cultural trade frictions}

Geographical trade frictions are well-known for their robust negative impact on bilateral trade flows. In particular, geographical distance and (the absence of) common borders

\footnotetext{
${ }^{15}$ Baier and Bergstrand (forthcoming) provide an analysis of the trade friction effects with panel data. While they include fixed effects to avoid biased estimates of the parameters, a compulsory quantification of the effect of trade frictions cannot be retrieved in their case (see Feenstra, 2004).

${ }^{16}$ More precisely, that research sought to provide an explanation of the strong, negative effect of national borders on trade volumes among Canadian provinces and U.S. states as compared to that of state and province borders on inter-regional trade within these two countries.
} 
should be mentioned here (e.g. Bergstrand 1985; 1989; Anderson and VanWincoop 2004). We compute bilateral great circle distances $\left(D I S T_{i j}\right)$ between two countries' capitals based on the longitude and latitude as published in the CIA World Factbook. The same source provides information on a country's common borders with other economies. Since our focus is on trade frictions, we depart from previous research by designing a dummy variable that takes the value one in the absence of a common border and zero otherwise $\left(N B O R D_{i j}\right)$. Furthermore, we follow the same principle by defining a cultural (language) distance variable that is one in the absence of a common official language and zero otherwise $\left(N L A N G_{i j}\right)$.

\subsection{Political trade frictions: regional trade agreements and an- tidumping investigations}

We use several different binary political trade friction indicators. Most importantly for the purposes of this paper, we employ variables giving the number of $\mathrm{AD}$ investigations of an importer against its exporting trading partner. ${ }^{17}$ We use this information on AD activity to construct two variables (and lags thereof) for use in our empirical models. The first is a count variable reflecting the number of $\mathrm{AD}$ investigations importing country $j$ has initiated against exporting country $i$ in year $t\left(A D_{i j t}\right)$. We expect the parameter of $A D_{i j t}$ to be negative if concurrent $\mathrm{AD}$ investigations impede exports of a country whose

\footnotetext{
${ }^{17}$ Data on antidumping investigations are collected from various sources. First of all, we take advantage of Chad Bown's series of antidumping cases from the year 1980 onwards. The data are available in tables format at http://people.brandeis.edu/ cbown/global_ad/. In fact, much more information is available there than we make use of and these data may be a rich source for future research.

In addition to Bown's data, we have compiled data on bilateral antidumping investigations before 1980. In particular, data on the European Union's (then, the European Community's) investigations are collected in the appendix to Beseler and Williams (1986). The data on Australia, South Africa, United Kingdom, and the United States stem from the from the General Agreement on Trade and Tariffs (GATT), in particular the supplement to its Basic Instruments and Selected Documents and national sources, for example: Australian Customs Service, Canada Customs and Revenue Agency, the DTI (for South Africa), and other countries' agencies Bruce Blonigen provides web-links on his homepage to a set of countries' administrative offices.

Note that Zanardi (2006) provides information at the unilateral level by summarizing the investigations at the investigator country level as available from the GATT's supplement to its Basic Instruments and Selected Documents publication. While Zanardi's article is a rich source as well, it is not useful for our purpose due to the absence of country-pair information for investigations.
} 
firms have been filed on. In addition, we allow for a separate impact of an accumulation of investigations at the country-pair level. Specifically, we use the cumulative number of AD investigations for a country-pair, indicating how many AD investigations economy $j$ has launched against country $i$ until year $t\left(C A D_{i j t}\right)$. This would reflect a particularly long memory in trade response to earlier investigations.

Following other work, we use information on (the absence of) common regional trade agreement membership for each country-pair and year, one for customs unions $\left(N C U_{i j t}\right)$ and the other one for free trade areas $\left(N F T A_{i j t}\right)$ as notified to the WTO. ${ }^{18}$

\subsection{Definition of the trade friction variable $t_{i j t}$}

While we have used a single symbol $t_{i j t}$ for trade costs in section 3 , the preceding subsections suggest that $t_{i j t}$ is an aggregate of $A D_{i j t}, C A D_{i j t}, N C U_{i j t}, N F T A_{i j t}, D I S T_{i j}$, $N B O R D_{i j}$, and $N L A N G_{i j} \cdot{ }^{19}$ In the aggregation, we follow the literature by assuming a log-linear functional form

$$
\begin{aligned}
\ln t_{i j t} & =\alpha_{1} A D_{i j t}+\alpha_{2} C A D_{i j t} \\
& +\alpha_{3} N C U_{i j t}+\alpha_{4} N F T A_{i j t} \\
& +\alpha_{5} \ln D I S T_{i j}+\alpha_{6} N B O R D_{i j}+\alpha_{7} N L A N G_{i j} .
\end{aligned}
$$

Following Anderson and VanWincoop (2003), we use $\ln x_{i j t} \equiv \ln X_{i j t}-\ln Y_{i t}-\ln Y_{j t}$ instead of $X_{i j t}$ as the left-hand-side variable in the sequel.

To implement the Baier-Bergstrand approximation, for each variable in $\ln t_{i j t}$ we collect terms in (9) into a variable indicated by a tilde. For instance, the term correspond-

\footnotetext{
${ }^{18}$ In the sensitivity analysis summarized in Table 2, we allow for a further impact of other preferential trade agreements notified to the WTO, WTO non-membership of either one or two countries of a pair, and the absence of currency arrangements such as currency union, currency peg, or currency band membership as documented by the IMF. Also, we consider the role of once and twice lagged antidumping $\left(A D_{i j, t-1}\right.$, $\left.A D_{i j, t-2}, C A D_{i j, t-1}, C A D_{i j, t-2}\right)$ and, finally, we use an exporter's antiduming investigations against the importer $\left(A D_{j i t}, C A D_{j i t}\right)$ as additional control variables there to capture dynamic effects of antidumping and sluggish response of trade flows to antidumping.

${ }^{19}$ Analogously, the other trade friction indicators mentioned above will be included in the sensitivity analysis of Sub-section 5.2.
} 
ing to $\ln D I S T_{i j}$ is the first-order Taylor-series approximation evaluated at an equilibrium with symmetric but non-zero trade frictions as in (9) which reads $\ln \widetilde{D I S T}_{i j} \equiv$ $\ln D I S T_{i j}-\frac{1}{N} \sum_{j=1}^{N} \ln D I S T_{i j}+\frac{1}{2} \frac{1}{N^{2}} \sum_{i=1}^{N} \sum_{j=1}^{N} \ln D I S T_{i j}$, and similarly for all other trade barrier variables. Note that the latter approximation reveals an analogy to the two-way panel data within estimator (here, with fixed exporter-by-time and importer-bytime effects). Variable $\ln \widetilde{D I S T}_{i j}$ is defined as the exporter-by-year and importer-by-year demeaned $D I S T_{i j}$, and similarly for the other trade barrier variables. The only difference by comparison to the two-way within model is that the left-hand-side variable is not demeaned in the Baier and Bergstrand (2006) approach.

Inserting (11) in (9) and using the above definitions yields

$$
\begin{aligned}
\ln x_{i j t} & =-\ln Y_{W, t}-(\sigma-1) \ln \alpha_{1} \ln \widetilde{A D}_{i j t}-(\sigma-1) \alpha_{2} \widetilde{C A D}_{i j t} \\
& -(\sigma-1) \alpha_{3} \widehat{N C U}_{i j t}-(\sigma-1) \alpha_{4}{\widetilde{N F T A_{i j t}}}(\sigma-1) \alpha_{5} \ln \widetilde{D I S T}_{i j} \\
& -(\sigma-1) \alpha_{6} N \widetilde{B O R} D_{i j}-(\sigma-1) \alpha_{7} \widehat{N L A N} G_{i j}+u_{i j t} .
\end{aligned}
$$

The specification in (12) could be estimated by either adding $\ln Y_{W, t}$ to both sides of the model or, in a less restrictive approach, by replacing $-\ln Y_{W, t}$ by fixed time effects. ${ }^{20}$ If the number of country-pairs in the data is as large as in our application, one can apply a country-pair within estimator to eliminate the possible correlation of the covariates with $\mu_{i j}$. The parameter estimates $\alpha_{k}$ for $k=1, \ldots, 4$ are then the fixed effects benchmark coefficients.

\footnotetext{
${ }^{20}$ Then, the coefficient of $-\ln Y_{W, t}$ does not have to be unity any more.
} 


\section{Panel data estimates of the impact of antidumping investigations on trade volumes}

\subsection{Baseline results}

In the empirical analysis, we proceed in two steps. First, we estimate the counterpart to (12) that uses non-demeaned trade friction variables on the right-hand side. While this model accounts for the possible influence of time-invariant variables, it ignores the impact of multilateral resistance on trade volume. ${ }^{21}$ Second, we summarize the findings of the transformed model as in (12). A comparison of the corresponding model outcome with that one based on the properly demeaned model sheds light on the importance of multilateral versus bilateral effects of trade frictions on trade volume in general and of $\mathrm{AD}$ in particular. The null hypothesis of a zero impact of multilateral resistance is even testable.

We run each of these two models by pooled ordinary least-squares (OLS) and the fixed country-pair effects estimator. Pooled OLS assumes that the included explanatory variables are uncorrelated with the time-invariant unobservables that are collected in the between error term $\left(\mu_{i j}\right)$ while the fixed effects model does not. Since the geographical and cultural variables in the model $\left(\ln D I S T_{i j}, N B O R D_{i j}, N L A N G_{i j}\right)$ are time-invariant, they will be wiped out by the fixed country-pair effects estimator so that their coefficients are only reported with pooled OLS.

- Table $1-$

Table 1 provides a summary of results for the four models. The results suggest the following conclusions. First, the test statistics reject the pooled OLS Models A and C against their fixed country-pair effects counterparts B and D. Second, Models A and B

\footnotetext{
${ }^{21}$ With panel data, the multilateral resistance terms can principally be captured by fixed exporter-bytime and importer-by-time effects-see Baltagi, Egger and Pfaffermayr (2003) for such a model. However, with a large data set as ours this involves a huge matrix of dummy variables that is infeasible to handle by standard computer hardware.
} 
ignore the role of multilateral resistance and are rejected against their cum-multilateralresistance-term counterparts, Models C and D. Since Model D is clearly preferable on econometric grounds over Models A-C, we focus on the discussion of the corresponding parameters in the sequel.

The point estimates for the parameter of $A D_{i j t}$ indicates that a single $\mathrm{AD}$ investigation exerts a significantly negative, contemporaneous, direct impact on bilateral export of about $e^{-0.073} \simeq-7.03 \%{ }^{22}$ According to the much smaller (in absolute value) and insignificant parameter of $C A D_{i j t}$, there is no indication of a long memory in trade responsiveness to $\mathrm{AD}$ in that model. Hence, investigations of an importer against an exporter in the past do not impede concurrent trade volume.

\subsection{Sensitivity analysis}

Before turning to the quantification of the impact of $\mathrm{AD}$ investigations on trade volume, we provide a sensitivity analysis of the baseline estimates in Table 1. Overall, we provide nine alternative sets of results for the parameters of interest (namely, those of $A D_{i j t}$ and $\left.C A D_{i j t}\right)$. Our findings are summarized in Table $2 \mathrm{~A}$.

- Table $2-$

Experiment (i)-including further trade friction variables: In a first step, we augment our specification of Model D by six additional covariates related to trade frictions: absence of preferential (other than customs union of free trade area) membership; absence of WTO membership for one of the two countries; absence of WTO membership for both countries; absence of currency union membership; absence of currency peg membership; absence of currency band membership. Most of these variables have been shown to affect trade volumes. As we note in the introduction, all of these variables have been shown, at

\footnotetext{
${ }^{22}$ This magnitude may strike the reader as quite large. However, note that this reflects only the direct impact of $A D_{i j t}$ on trade flows within an overall highly nonlinear framework. A valid quantification of the effect of antidumping investigations is quite tricky, here, since we have to compute the associated change of $\widetilde{A D}_{i j t}$ through an increase in $A D_{i j t}$ for all country-pairs. We pursue this explicitly in section 5.4 , where we will see that this ends up being a very small effect.
} 
least in some analyses, to significantly affect trade patterns. Indeed, we find that these variables exert a jointly significant (at one percent) impact on bilateral exports. However, their omission does not influence the point estimates of the parameters of interest, $\beta_{A D_{i j t}}$ and $\beta_{C A D_{i j t}}$.

Experiments (ii) and (iii)-dynamic effects of antidumping: By including $C A D_{i j t}$ along with $A D_{i j t}$, Model $\mathrm{D}$ accounts for a dynamic effect of $\mathrm{AD}$ on trade volume, but in a very crude way. In Experiment (ii) we include once lagged levels of our AD variables $\left(A D_{i j, t-1}, C A D_{i j, t-1}\right)$ to the specification in Experiment (i), and in Experiment (iii) we additionally include the twice lagged levels thereof $\left(A D_{i j, t-2}, C A D_{i j, t-2}\right)$. Hence, these specifications capture time-variant influence of contemporaneous versus lagged AD investigations as in autoregressive distributed lag models. Since we are interested in the long-run effects of $\mathrm{AD}$ in the sequel, we report its cumulated impact with these two experiments $-\beta_{A D_{i j t}}+\beta_{A D_{i j, t-1}}\left(+\beta_{A D_{i j, t-2}}\right)$ and $\beta_{C A D_{i j t}}+\beta_{C A D_{i j, t-1}}\left(+\beta_{C A D_{i j, t-2}}\right)$, respectively. We find that the fixed effects estimator of Model D substantially underestimates the impact of both current and cumulative investigations; however, we also find that the inclusion of a second lag provides essentially no additional impact on trade volume. ${ }^{23}$

Experiment (iv)-the exporter's investigations and their impact on bilateral export volume: In the next experiment, we include the exporter's AD investigation variables $A D_{j i t}$ and $C A D_{j i t}$, respectively, in addition to the covariates in Experiment (iii). We do so to make sure that we do not ascribe an effect to the importer's investigations that in fact is due to exporter activity. Again, these two variables contribute significantly to the explanation of bilateral, normalized export volume. However, the parameters of interest are not statistically different from those in Experiment (iii) as can be seen from the point estimates and the $t$-statistics reported in Table 2.

Experiment (v)-systematically missing trade values: Recent research provides an explanation of zero trade among trading partners with particular characteristics (e.g. Evenett and Venables, 2002; Felbermayr and Kohler, 2006; Helpman, Melitz and Rubin-

\footnotetext{
${ }^{23}$ This holds true although not only the once lagged but also the twice lagged antidumping investigation variables contribute significantly to the model. We have run specifications with even more than two lags, but the results remain stable.
} 
stein, 2006). With a log-linear model like ours, the dependent variable may be missing for three reasons: bilateral trade is truly zero; bilateral trade values are not reported; ${ }^{24}$ or GDP values are not available. As a result, selection into the sample might lead to a biased impact of the AD investigation parameters of interest. We check for the sensitivity of the findings by correcting the specification as in Experiment (iv) for sample selection bias. ${ }^{25}$ We follow Wooldridge (1995) by applying a sample selection model that is suitable for panel data with fixed effects. ${ }^{26}$ This model rests on inverse Mill's ratios as selection correction variables that are based on annual probit models. These probit models employ the multilateral resistance transformed and untransformed variables as in Experiment (iv) and time-invariant geographical and cultural determinants (see Footnote $\mathrm{f}$ in Table 2 for details). In all years, these variables possess high joint relevance (they are significant at one percent throughout). A test of sample selection following Wooldridge (1995) indicates that there is significant (at one percent) selection into the sample conditional on this specification. However, there is little impact on the point estimates of the parameters of interest.

\section{Experiment (vi)-accounting for zero trade flows in a Poisson quasi-maximum-}

likelihood model: Recently, Santos Silva and Tenreyro (2006) suggest accounting for zero bilateral trade flows in a Poisson model. There, only the right-hand-side of the specification is logarithmically transformed but not the dependent variable. Hence, zero trade flows are not dropped by log-transforming the model. In our data-set, there are 588,095 zero bilateral export values across all years. Hence, the number of observations in the Poisson model is 882, 451 while it was only 294,356 in the log-export-based specifications. For the sake of consistent estimates, we follow the Mundlak-Chamberlain device and include country-pair means of all explanatory variables in the model along with the original variables. This leads to parameter estimates for the original variables that are to be interpreted as within country-pair estimates as in the previous models. Addition-

\footnotetext{
${ }^{24}$ Zero trade and missing trade values are typically not satisfactorily distinguishable in trade matrices.

${ }^{25}$ We do not use the model as of Experiment (v) since the use of GDP in the selection model leads to an unnecessary loss of observations.

${ }^{26}$ Cross-section procedures as in Helpman et al. (2006) or Felbermayr and Kohler (2006), are not applicable in this case, as pointed out by Wooldridge (1995).
} 
ally, the estimates are based on heteroskedasticity-robust standard errors as suggested by Santos Silva and Tenreyro (2006). Obviously, the estimated impact of $A D$ and $C A D$ is similar to the baseline results. While the point estimate for the impact of $A D$ on bilateral exports is higher than before, the parameter is not significantly different from the original estimates

Experiment (vii)-using the number of impositions of preliminary antidumping measures instead of the investigations: We might reasonably expect that the primary effect of $\mathrm{AD}$ on trade comes only with the actual imposition of $\mathrm{AD}$ duties. Unfortunately, neither Bown's data (which begin in 1980) nor the data we have been able to collect permit us to treat this question over the entire GATT/WTO time period. Thus, as an additional experiment, we consider the subperiod from 1980. Interestingly, the results point to a somewhat smaller point estimate of the long run impact of impositions than for investigations for the longer time span. However, the parameter estimates are not significantly different between Experiments (iv) and (vi). ${ }^{27}$

Experiments (viii)-using GDP-weighted rather than simple averages in the Baier and Bergstrand (2006) approach to account for multilateral resistance: Baier and Bergstrand suggest an alternative specification of multilateral resistance, where the original trade friction variables are not transformed by subtracting simple exporter and importer means but rather GDP-weighted ones. The latter transformation is associated with a Taylor-series approximation around the zero trade friction equilibrium. This specification leads to a lower point estimate of the $A D$ impact. However, this effect is estimated at less precision than the original ones so that it is not significantly different from the baseline estimates.

Based on the analysis in this section we will generally use the specification in experiment (iv) as our main framework. In addition, we will compare the results from this specification against ones that are based on applied measures as in experiment (vii).

\footnotetext{
${ }^{27}$ One explanation for this may be the high correlation between non-transformed and transformed antidumping investigations and the impositions of antidumping measures. The correlation coefficients amount to 0.64 and 0.62 (impositions), respectively.
} 


\subsection{Discussion of hypotheses on trade volume effects of anti- dumping}

In section 2 we presented four broad classes of channel that the literature on AD has identified as affecting trade volumes: direct protection effects; effects due to contingent nature of protection; effects due to non-MFN nature of protection; and effects due to firmspecific nature of protection. In section 3 we developed the model that resulted in our empirical specification in equation (12). In this section we express the predicted effects as hypotheses of this model and present some estimates of these effects. Section 5.4 will present our analysis of the quantitative magnitude of the major effects.

The most obvious implementation of our key question is to ask whether the use of AD by country $j$ on the imports from country $i$ (implemented as exports from $i$ to $j$ ) reduces the volume of those imports. In terms of the specification in equation (12), this implies that $\alpha_{1}<0$. As the estimates reported in table 2 suggest, we do find a statistically significant negative effect of AD in the year of initiation. In our sensitivity analysis, we also considered one and two period lags of $A D$, both of which are significant. More importantly, it is clear that inclusion of one lag is necessary to capture the effects of $\mathrm{AD}$ on trade in a given period, but that the second lag contributes little to the analysis. Because the data on applied measures are not available for many countries over the entire time period of interest, we have defined our $A D$ (and $C A D$ ) variables in terms of initiations. Given data availability and a reasonably high correlation between initiations and application of duties, this seems a sensible strategy. However, experiment (iv) directly examines the number of cases in which duties were applied as a robustness check. Consistent with our expectations, $\alpha_{1}$ is negative and statistically significant with a magnitude roughly similar (in fact, slightly smaller) to the value of the parameter estimated in our baseline specification estimated on initiations. ${ }^{28}$

\footnotetext{
${ }^{28}$ Using data from Bown's data-set, so covering the period 1980-2001, we also considered specifications in which $A D$ was implemented as each component: duties; suspension agreements; and price undertakings. Specifications involving the contemporaneous values, one and two lags of these variables were considered. With the exception of a specification in which two lags of price undertakings were considered, none of these achieved conventional levels of significance. The specification involving one and two lags of the
} 
It is interesting to note that the coefficient on our $C A D$ variable, $\alpha_{2}$, is greater than zero. This variable is intended to pick up the long-run effects of $A D$ in the relevant dyad. We capture the contemporaneous, the once-lagged, and the twice-lagged impact in $\alpha_{1}$, so those countries that applied many AD-measures in the past now have fewer of them. $^{29}$ For the overall impact of $A D$ note that a country's cumulative number of $\mathrm{AD}$ actions grows by definition, while contemporaneous ADs may increase or fall over time. Altogether, the cumulative impact (through $\alpha_{2}$ ) reduces the contemporaneous one. The smaller the change relative to a dyad's average number of $\mathrm{AD}$ actions across the years in a given time span, the smaller is the reduction of the direct impact of $A D$ (through $\alpha_{1}$; for a given dyadic change in $A D$ over time) by that of the cumulative one (through $\left.\alpha_{2}\right)$. Hence, $\alpha_{2} \cdot C A D$ reduces the impact of $\alpha_{1} \cdot A D$, and this reduction depends on the level and change in both $A D$ and $C A D .{ }^{30}$ This effect might be picking up some of the retaliation effects, which we consider explicitly below.

A second set of hypotheses relate to the firm-specific effects of $\mathrm{AD}$ protection. We considered two broad arguments here: harassment; and strategic effects. In the case of harassment, we would expect the effect to flow from initiation, so we can use our full dataset. The hypothesis would be $\alpha_{1}<0$. In the case of strategic effects, it is not clear whether we should be focusing on initiations or implementations, but in either case the hypothesis is $\alpha_{1}<0$. As with the hypothesis of general direct effects we do find a statistically significant negative impact of both initiation and implementation. Since these three hypotheses make observationally equivalent predictions, our results do not allow us to choose between hypotheses. ${ }^{31}$ We can, however, consider the magnitudes involved. We

price-undertaking variable was significantly negative, though the cumulative impact of the two lags was not significant. Full results are available on request.

${ }^{29}$ This is precisely the pattern of use that we see in figures 2 and 3, where both initiations and implementations by traditional users have declined over time while use by new users has increased dramatically.

${ }^{30}$ It should be noted that, since our framework explicitly incorporates multilateral resistance, the overall impact of AD activity (both contemporaneous and cumulative) also depends on what happens in the other dyads.

${ }^{31}$ As we noted in section 2: for strategic effects to be macroeconomically significant (and thus show up in analysis of the sort we consider here) would require implausible market structure conditions at the global level; and econometric work at the microeconomic level has not found much in the way of support for the harassment hypothesis (Staiger and Wolak, 1994, 1996). Thus, we are predisposed to believe that the effects we have identified flow from direct effects. 
consider this in the next section.

A third set of hypotheses derive from the non-MFN nature of AD protection. The essential issue here is trade diversion. In thinking about trade diversion in the context of a gravity model, there are several important things to note. First, the direct impact of a country's AD investigations on dyadic exports-given everybody else's actions-is identical to the parameter in Table 2 (of course, our left-hand-side variable is in logs, so the elasticity in percent would be about $100 \cdot\left(e^{\alpha_{1}-\operatorname{Var}\left(\alpha_{1}\right)}-1\right) .{ }^{32}$ Second, the impact on the average dyadic number of $\mathrm{AD}$ investigations for the average exporter in year $t$ is quite small as is that on the average dyadic number of $\mathrm{AD}$ investigations for the average importer. The impact on the overall average dyadic number of $\mathrm{AD}$ investigations for all pairs is even smaller. The negative of the change in exporter-by-time average number of AD investigations minus that of the importer-by-time average number of $\mathrm{AD}$ investigations plus that of the time average number of $\mathrm{AD}$ investigations is the third-country change [i.e. $\Delta\left(-\overline{A D}_{\cdot j t}-\overline{A D}_{i \cdot t}+\overline{A D}_{\cdot t}\right)$, where $\Delta$ is the first difference operator]. Recall that-in contrast to the following table-we're talking about the "marginal" impact of a single AD investigation on bilateral trade here. Clearly, the direct impact of AD on trade is captured by $\alpha_{1} \Delta A D_{i j t}=\alpha_{1}$ from which it follows that the effect due to multilateral resistance is $\alpha_{1} \Delta\left(-\overline{A D}_{\cdot j t}-\overline{A D}_{i \cdot t}+\overline{A D}_{\cdot t}\right)<1$; since the parameter for both effects is the same, the diversion effect is smaller than the creation effect (of course, since $\alpha_{1}<0$, here, we're faced with a negative creation effect). Beyond that, we may say that with a world-wide increase of usage, the diversion effect will decline, since the means will be affected less than before by a unitary increase of a single country's AD investigations but the direct effect is always multiplied by $\Delta A D_{i j t}=1$. The latter has some interesting implications. For instance, if there is a clustered entry into the group of AD mechanism access-group, the diversion effect for a single country is smaller in the phase of clustered entry while it is relatively larger in a phase without clustered entry and usage. On the other hand, the world-wide overall diversion effect is then large, since all countries together have a

\footnotetext{
${ }^{32}$ Note that the effect of a unitary change in $\mathrm{AD}$ on exports is not well approximated by $100 \cdot\left(e^{\alpha_{1}}-1\right)$ in a semi-log model as indicated by Van Garderen and Shah (2002).
} 
sizeable impact on the change of the means.

- Table 3A -

A third set of hypotheses involves contingent protection effects, or what Vandenbussche and Zanardi (2006) call the "global chilling effect"-the effect on all trading partners of $\mathrm{AD}$ protection levied on any trading partner. In Table 3A we report three specifications in the spirit of VZ: using the sum of all AD initiations by country $j$ against any country in year $t$, in addition to the dyad-by-year specific terms (Table 3A, Case 1); using the sum of all $\mathrm{AD}$ implementations by country $j$ against any country in year $t$, in addition to the dyad-by-year specific terms (Table 3A, Case 2); and introducing both of these variables at the same time (Table $3 \mathrm{~A}$, Case 3). ${ }^{33}$ That is, we consider $A D_{j t}$ and $C A D_{j t}$ in addition to $A D_{i j t}$ and $C A D_{i j t}$. In no case are these variables significant, and the sign pattern among specifications is also unstable. Thus, we find no evidence in favor of "global chilling".

\section{- Table 3B -}

Retaliation is a more complex direct effect of AD. We saw in section 2 that retaliation has both a trade reducing and trade increasing effect, and that these effects might be conveyed by simply adopting an AD mechanism; by initiation, and/or by implementation. Thus, we consider a number of specifications. Specifically, we construct a dummy which takes the value of unity if the exporter (country $i$ ) initiated an $\mathrm{AD}$ action against the importer (country $j$ ) in period $t$ or any other year before. We also consider this variable interacted with the number of $\mathrm{AD}$ actions. We then use these variables in both specifications (iii) and (iv) (Table 3B, Cases 4-7). It turns out not only that these new variables are not significant but, as can be seen from the first four cases in table 3B, the values of $\alpha_{1}$ and $\alpha_{2}$ are essentially unchanged. Finally, we consider a specification with three dummy variables: one each for whether the importer and exporter possess an $\mathrm{AD}$ mechanism (variable takes a value of unity if yes), and an interaction term if both possess

\footnotetext{
${ }^{33}$ We can only use the full sample for the first specification. For the other two we can only use 1980-2001.
} 
an $\mathrm{AD}$ mechanism (Table 3B, Case 8). If retaliation were significant, we would expect the interaction term to be significant. ${ }^{34}$ This is not the case. Thus, unless we want to consider $C A D$ and $\alpha_{2} \cdot C A D$ as evidence of retaliation, we find no evidence in favor of this hypothesis.

\subsection{Quantification of the antidumping effect on trade volume between 1960 and 2000}

Because we expect $\mathrm{AD}$ activity to affect long-run, as well as current, trade, we use the model as in Experiment (iv) of Table 2 to quantify the impact on exports among the covered economies. For this, we compare the contribution of $\mathrm{AD}$ alone to the predicted change in various aggregates of the normalized export volume between 1960 and 2000. Denote the predicted change in normalized exports by $\Delta \ln \hat{x}_{i j} \equiv \ln \hat{x}_{i j, 2000}-\ln \hat{x}_{i j, 1960}$ and the corresponding counterfactual change, where $\widetilde{A D}_{i j, 2000}$ and $\widetilde{C A D}_{i j, 2000}$ (and their lags) are replaced by $\widetilde{A D}_{i j, 1960}$ and $\widetilde{C A D}_{i j, 1960}$ (and their lags) in $\ln \hat{x}_{i j, 2000}$. Denote the corresponding counterfactual change by $\left(\Delta \ln \hat{x}_{i j}^{c}\right)$. The difference between the two, $\Delta \ln \hat{x}_{i j}-\Delta \ln \hat{x}_{i j}^{c}$ is an estimate of the impact of AD investigations on trade between 1960 and 2000. The overall impact on export volume is the net effect of recent $(A D)$ and past $(C A D)$ changes in the number of investigations.

We consider the effect of $\mathrm{AD}$ investigations on three different averages of world trade volume: first, the average country-pair in the sample (trade-weighted); second, the average (trade-weighted) country-pair with an investigation importer (being defined as one where the cumulative number of investigations is greater than zero in the year $2000, C A D_{i j, 2000}>$ $0)$; third, the (trade-weighted) average impact on country-pairs where the importer has never investigated $\left(C A D_{i j, 2000}=0\right)$. Table 4 summarizes our findings.

- Table 4 -

The table suggests that the impact on exports is rather small. The reason for this

\footnotetext{
${ }^{34}$ The individual dummies take the same signs as the count variables tapping the same policies. Note that, again, the parameters of the $A D$ and $C A D$ variables are essentially unchanged.
} 
is that, on average, $\widetilde{A D}_{i j, 1960}, \widetilde{A D}_{i j, 2000}, \widetilde{C A D}_{i j, 1960}, \widetilde{C A D}_{i j, 2000}$, and, most importantly, their changes are rather small (see Table 5 in the Appendix). For the average countrypair, the decline in bilateral exports between 1960 and 2000 that is attributable to AD investigations is slightly more than a tenth of a percentage point. Of this, about 80 percent are due to the direct effect of bilateral $\mathrm{AD}$ rather than multilateral resistance. However, multilateral resistance tends to raise the impact and, on average, works in the same direction as the direct effect. Exports into AD-applying importers declined by about 1.6 percentage points over the same four decades. For these pairs, multilateral resistance accounted for more than a third of the effect. Exports into non-AD-applying importers increased marginally by about a third of a percentage point which was entirely due to multilateral resistance.

\section{Welfare effects of antidumping}

In addition to calculating the effect on trade volumes, we can also use our structural framework to estimate the welfare effects of antidumping as the equivalent variation in percent associated with an annual change in $\mathrm{AD}$ and CAD for country $i$. For this, let us define the estimated contribution of the $k$ th trade friction variable to country $i$ 's predicted bilateral $\log$ exports to country $j$ in the year $t$ as $\widehat{\beta_{k}} \widetilde{\ln } t_{k, i j, t}$, according to (9). For instance, log bilateral trade due to contemporaneous antidumping would then be $\widehat{\beta}_{A D} \widetilde{A D}_{i j, t}$. With unitary GDP coefficients, a prediction of GDP-normalized bilateral exports is then

$$
\frac{\widehat{X_{i j, t} Y_{W, t}}}{Y_{i, t} Y_{j, t}}=e^{\sum_{k} \widehat{\beta_{k}} \widetilde{\ln t_{k, i j, t}}}
$$

According to the model assumptions, $\sum_{j=1}^{N} \widehat{X}_{i j, t}=\widehat{Y}_{i, t}$. Using antidumping variables as of $t-1$ but other trade frictions as of the year $t$ to construct counterfactual trade frictions in $\operatorname{logs}$ as of $t$, referred to as $\widehat{\beta_{k}} \widetilde{\ln }_{k, i j, t, c}$, we may estimate counterfactual bilateral exports 
$\left(\widehat{X}_{i j, t, c}\right)$ and GDP $\left(\widehat{Y}_{i, t, c}=\sum_{j=1}^{N} \widehat{X}_{i j, t, c}\right) .{ }^{35}$ Then, the equivalent variation for country $i$ in percent according to the observed change in $A D$ and $C A D$ between 2000 and $t$ evaluated at other variable levels as of the year $t$ is defined as

$$
\widehat{E V}_{i, t}=100\left(\frac{\widehat{Y}_{i, t}}{\widehat{Y}_{i, t, c}} \frac{\widehat{P}_{i, t, c}}{\widehat{P}_{i, t}}-1\right)
$$

where $\widehat{P}_{i, t}=\left(e^{\sum_{k=1}^{K}\left[-\frac{1}{N} \sum_{j=1}^{N} \widehat{\beta_{k}} \ln t_{k, i j, t}+\frac{1}{2} \frac{1}{N^{2}} \sum_{i=1}^{N} \sum_{j=1}^{N} \widehat{\beta_{k}} \ln t_{k, i j, t}\right]}\right)^{\frac{1}{1-\sigma}}$ is the CES price index at original trade frictions in the year $t$ and $\widehat{P}_{i, t, c}$ is similarly defined for counterfactual trade frictions. Since the elasticity of substitution parameter is not estimated directly, we follow Anderson and van Wincoop (2003) by assuming a level of $\sigma=5$. Under this assumption, we estimate an average annual welfare effect of antidumping that is about -0.01 percent. The average annual effect on $\mathrm{AD}$-applying countries is about -0.05 percent and that on $\mathrm{AD}$-non-applying countries is about 0.002 percent, respectively. The maximum estimated annual welfare effect of $\mathrm{AD}$ amounts to less than 1.5 percent. The average annual reduction for the US amounts to 0.06 percent. ${ }^{36}$ The maximum estimated annual AD-induced reduction in welfare for the US over the period 1960 to 2000 amounts to less than 0.23 percent. Hence, consistent with the small impact on trade flows, the estimated welfare effects of antidumping are small.

\section{Conclusions}

Overall, then, our analysis suggests that the aggregate effects of $\mathrm{AD}$ in the context of the GATT/WTO system are modest. This should not be taken to imply that AD is not, or should not be, a matter of concern to the Liberal international trading system. Given

\footnotetext{
${ }^{35}$ In particular, we estimate $\widehat{Y}_{i, t, c}$ by using $\frac{\widehat{Y}_{i, t, c}}{\widehat{Y}_{i, t}} \approx \frac{\sum_{j=1}^{N} \frac{X_{i j, t, c} \widehat{Y}_{W, t, c}}{Y_{i, t, c} Y_{j, t, c}}}{\sum_{j=1}^{N} \frac{X_{i j, t} Y_{W, t}}{Y_{i, t} Y_{j, t}}}$.

${ }^{36}$ The only other estimate of the welfare effect of antidumping that we know of is that of Gallaway et al. (1999). As we note above, they estimate that antidumping in 1993 reduced US welfare a maximum of 0.06 percent (i.e. $\$ 2-4$ billion welfare reduction in a year where US GDP was estimated to be $\$ 6.7$ trillion). This is remarkably close to our average annual estimate for the US. In any event, both estimates are very small.
} 
the magnitude of duties, the sectoral distortions can be quite sizable. In addition, the control of protection and the advance of liberalization are the centerpieces of that system and $\mathrm{AD}$ protection is protection. At the same time, it does not seem useful to oversell the consequences of AD. Since it seems likely that contingent protection has played an important role in supporting trade liberalization, reflexive rejection seems particularly inappropriate.

This last point strikes us as important. As economists, our first line of response to $\mathrm{AD}$ is surely negative. We applaud the reductions in tariffs associated with various trade liberalizations, but abhor the "backsliding" associated with administered protection. The moral language is used advisedly: most of us view liberalization as an act of moral courage, and reversals as moral weakness. Close students of $\mathrm{AD}$, however, have long been clear that the reality is considerably more complex. The effects on which this paper has focussed are essentially micro-effects. That is, they refer to the effects within country-pairs (and, at least intuitively, are driven by firm/sector level effects). While such micro effects have been the focus of the great majority of both theoretical and empirical research on $\mathrm{AD}$, systemwide ("macro") effects have also been noted (Nelson, 2006). The "global chilling effect" is in principle a macro effect, but we were unable to find any evidence of its presence. Strongly positive macro effects have also been commented upon. From the very earliest research on AD (e.g. Viner, 1923), it has been recognized that AD can be a central part of a political strategy to support liberalization. Recent work by Finger and Nogues (2005) provides strong case study evidence that, at least in a number of Latin American countries engaged in liberalization episodes in the 1980s, AD was used in precisely this way. To the extent that the Liberal trading system that began to emerge in the late-1930s and was institutionalized in the GATT/WTO system relied on US leadership, and that that leadership was conditional on the various reciprocal trade acts and their more modern descendants, it is clear that administered protection played a central role in underwriting the system as a whole. While such system-wide macro effects are purely speculative, the generally small micro effects suggest at a minimum that we need much more information on the way contingent protection interacts with statutory protection and multilateral 
liberalization. 


\section{A Appendix: Country coverage}

Afghanistan, Albania, Algeria, Angola, Argentina, Armenia, Aruba, Australia, Austria, Azerbaijan, The Bahamas, Bahrain, Bangladesh, Barbados, Belarus, Belgium, Belize, Benin, Bermuda, Bolivia, Bosnia and Herzegovina, Botswana, Brazil, Brunei, Bulgaria, Burkina Faso, Burundi, Cambodia, Cameroon, Canada, Cape Verde, Central African Republic, Chad, Chile, China, Colombia, Comoros, Rep. Congo, Costa Rica, Cote d'Ivoire, Croatia, Cuba, Cyprus, Czech Republic, Denmark, Djibouti, Dominican Republic, Ecuador, Egypt, El Salvador, Equatorial Guinea, Eritrea, Estonia, Ethiopia, Fiji, Finland, France, French Polynesia, Gabon, The Gambia, Georgia, Germany, Ghana, Greece, Guatemala, Guinea, Guinea-Bissau, Guyana, Haiti, Honduras, Hong Kong (China), Hungary, Iceland, India, Indonesia, Islamic Rep. Iran, Iraq, Ireland, Israel, Italy, Jamaica, Japan, Jordan, Kazakhstan, Kenya, Rep. Korea, Kuwait, Kyrgyz Republic, Lao PDR, Latvia, Lebanon, Lesotho, Liberia, Libya, Lithuania, Luxembourg, Macao (China), FYR Macedonia, Madagascar, Malawi, Malaysia, Mali, Malta, Mauritania, Mauritius, Mexico, Fed. Sts. Micronesia, Moldova, Mongolia, Morocco, Mozambique, Myanmar, Namibia, Nepal, Netherlands, Netherlands Antilles, New Caledonia, New Zealand, Nicaragua, Niger, Nigeria, Norway, Oman, Pakistan, Palau, Panama, Papua New Guinea, Paraguay, Peru, Philippines, Poland, Portugal, Puerto Rico, Qatar, Romania, Russian Federation, Rwanda, Samoa, Sao Tome and Principe, Saudi Arabia, Senegal, Sierra Leone, Singapore, Slovak Republic, Slovenia, Somalia, South Africa, Spain, Sri Lanka, St. Lucia, Sudan, Suriname, Swaziland, Sweden, Switzerland, Syrian Arab Republic, Tajikistan, Tanzania, Thailand, Togo, Tonga, Trinidad and Tobago, Tunisia, Turkey, Turkmenistan, Uganda, Ukraine, United Arab Emirates, United Kingdom, United States, Uruguay, Uzbekistan, Vanuatu, RB Venezuela, Vietnam, Rep. Yemen, Zambia, Zimbabwe. 


\section{References}

Anderson, J. (1979). A theoretical foundation for the gravity equation, American Economic Review 69(1): 106-116.

Anderson, J. and VanWincoop, E. (2003). Gravity with gravitas: A solution to the border puzzle, American Economic Review 93(1): 170-192.

Anderson, J. and VanWincoop, E. (2004). Trade costs, Journal of Economic Literature 42(3): 691-751.

Baier, S. and Bergstrand, J. (2006). Bonus vetus OLS: A simple approach of addressing the 'border puzzle' and other gravity equation issues. ms: Notre Dame University.

Baier, S. and Bergstrand, J. (forthcoming). Do free trade agreements actually increase members' international trade, Journal of International Economics .

Baldwin, R. (1994). Towards an Integrated Europe, Centre for Economic Policy Research, London.

Baltagi, B. (2005). Econometric Analysis of Panel Data, 3 edn, Wiley and Sons, New York, NY.

Baltagi, B., Egger, P. and Pfaffermayr, M. (2003). A generalized design for bilateral trade flow models, Economics Letters 80(3): 391-397.

Bergstrand, J. (1985). The gravity equation in international trade: Some microeconomic foundations and empirical evidence, Review of Economics and Statistics 67(3): 474481.

Bergstrand, J. (1989). The generalized gravity equation, monopolistic competition, and the factor-proportions theory in international trade, Review of Economics and Statistics 71(1): 143-153. 
Beseler, J. F. and Williams, A. N. (1986). Antidumping and Antisubsidy Law: The European Communities, Sweet and Maxwell, London.

Blonigen, B. and Bown, C. (2003). Antidumping and retaliation threats, Journal of International Economics 60(2): 249-273.

Blonigen, B. and Prusa, T. (2003). Antidumping, in E. K. Choi and J. Harrigan (eds), Handbook of International Trade, Blackwell, Oxford, pp. 251-284.

Bown, C. and Crowley, M. (2006a). Policy externalities: How US antidumping affects japanese exports to the EU, European Journal of Political Economy 22(3): 696-714.

Bown, C. and Crowley, M. (2006b). Trade deflection and trade depression. ms: Brandeis University and Federal Reserve Bank of Chicago.

Cheng, I.-H. and Wall, H. (2005). Controlling for heterogeneity in gravity models of trade, Federal Reserve Bank of St. Louis Review 87(1): 49-63.

Deardorff, A. (1998). Determinants of bilateral trade: Does gravity work in a neoclassical world?, in J. Frankel (ed.), The Regionalization of the World Economy, University of Chicago Press/NBER, Chicago, pp. 7-22.

Dixit, A. and Stiglitz, J. (1977). Monopolistic competition and optimum product diversity, American Economic Review 67(3): 297-308.

Evenett, S. and Venables, A. (2002). Export growth by developing economies: Market entry and bilateral trade. ms: St. Galen and LSE.

Falvey, R. and Nelson, D. (2006). 100 years of antidumping, European Journal of Political Economy 22(3): 545-553.

Feenstra, R. (2004). Advanced International Trade: Theory and Evidence, Princeton University Press, Princeton. 
Felbermayr, G. and Kohler, W. (2006). Exploring the extensive and intensive margins of world trade, Review of World Economics 142(4): 642-674.

Finger, J. M. and Nogues, J. (2005). Safeguards and Antidumping in Latin American Trade Liberalization: Fighting Fire with Fire, Macmillan Palgrave (World Bank), Houndmills, Basingstoke, Hampshire.

Frankel, J. (1997). Regional Trading Blocs in the World Economic System, Institute for International Economics, Washington, DC.

Frankel, J. and Rose, A. (2002). An estimate of the effect of currency unions on trade and growth, Quarterly Journal of Economics 117(2): 437-466.

Gallaway, M., Blonigen, B. and Flynn, J. (1999). Welfare cost of the US antidumping and countervailing duty law, Journal of International Economics 49(2): 211-244.

Glick, R. and Rose, A. (2002). Does a currency union affect trade? the time series evidence, European Economic Review 46(6): 1225-1251.

Hausman, J. (1978). Specification tests in econometrics, Econometrica 46(6): 1251-1271.

Helpman, E., Melitz, M. and Rubinstein, Y. (2006). Trading partners and trading volumes. ms: Harvard University.

Krishna, K. (1989). Trade restrictions as facilitating devices, Journal of International Economics 36(3/4): 251-270.

Krugman, P. (1979). Increasing returns, monopolistic competition, and international trade, Journal of International Economics 9(4): 469-479.

Leamer, E. (1987). Cross section estimation of the effects of trade barriers, in R. Feenstra (ed.), Empirical Methods for International Trade, MIT Press, Cambridge, pp. 52-82.

Leamer, E. (1990). The structure and effects of tariff and nontariff barriers in 1983, in R. Jones and A. Krueger (eds), The Political Economy of International Trade, Blackwell, Oxford, pp. 224-260. 
Leidy, M. (1994). Trade policy and indirect rent seeking: A synthesis of recent work, Economics and Politics 6(2): 97-118.

Nelson, D. (2006). The political economy of antidumping: A survey, European Journal of Political Economy 22(3): 554-590.

Prusa, T. (2001). On the spread and impact of antidumping, Canadian Journal of Economics 34(3): 591-611.

Prusa, T. and Skeath, S. (2002). The economic and strategic motives for antidumping filings, Weltwirtschaftliches Archiv 138(3): 389-413.

Rose, A. (2000). One money, one market: The effect of common currencies on trade, Economic Policy 15(30): 9-45.

Rose, A. (2004a). Do we really know that the WTO increases trade?, American Economic Review 94(1): 98-114.

Rose, A. (2004b). Do WTO members have more liberal trade policy?, Journal of International Economics 63(2): 209-235.

Rose, A. and VanWincoop, E. (2001). National money as a barrier to trade: The real case for a currency union, American Economic Review 91(2): 386-390.

Santos Silva, J. and Tenreyro, S. (2006). The log of gravity, Review of Economics and Statistics 88(4): 641-658.

Shin, H. J. (1998). Possible instances of predatory pricing in recent u.s. antidumping cases, in R. Lawrence (ed.), Brookings Trade Forum, Brookings Institution, pp. 81-97.

Staiger, R. and Wolak, F. (1994). Measuring industry-specific protection: Antidumping in the US, Brookings Papers on Economic Activity Microeconomics: 51-118.

Staiger, R. and Wolak, F. (1996). Differences in uses and effects of andidumping law across import sources, in A. Krueger (ed.), The Political Economy of American Trade Policy, University of Chicago Press/NBER, Chicago, pp. 385-415. 
Subramanian, A. and Wei, S.-J. (forth.). The WTO promotes trade, strongly but unevenly, Journal of International Economics .

Van Garderen, K. J. and Shah, C. (2002). Exact interpretation of dummy variables in semilogarithmic equations, Econometrics Journal 5: 149-159.

Vandenbussche, H. and Zanardi, M. (2006). The global chilling effects of antidumping law proliferation. CEPR Discussion Paper, no. 5597.

Viner, J. (1923). Dumping: A Problem in International Trade, University of Chicago Press, Chicago.

Wall, H. (1999). Using the gravity model to estimate the costs of protection, Federal Reserve Bank of St. Louis, Review (January/February): 33-40.

Wooldridge, J. (1995). Selection corrections for panel data models under conditional mean independence assumptions, Journal of Econometrics 68(1): 115-132.

Zanardi, M. (2006). Antidumping: A problem in international trade, European Journal of Political Economy 22(3): 591-617. 
Figure 1: Antidumping investigations initiated

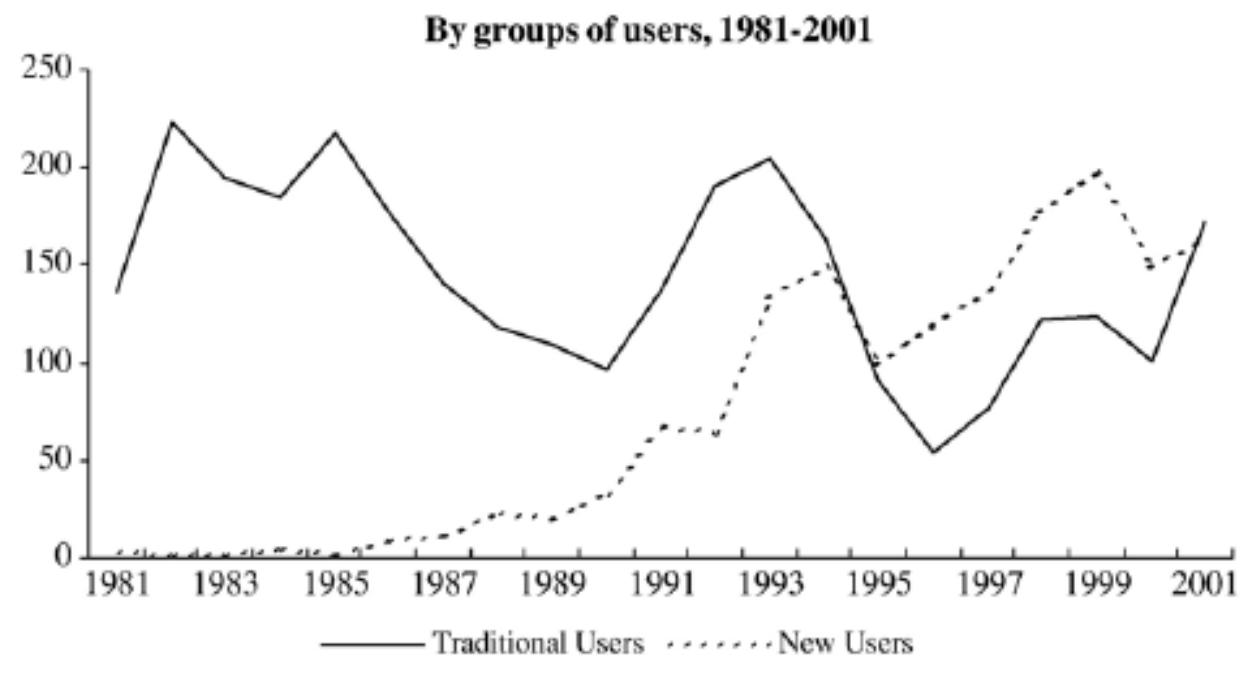

Source: Zanardi (2006, figure 2)

Figure 2: Antidumping measures in force

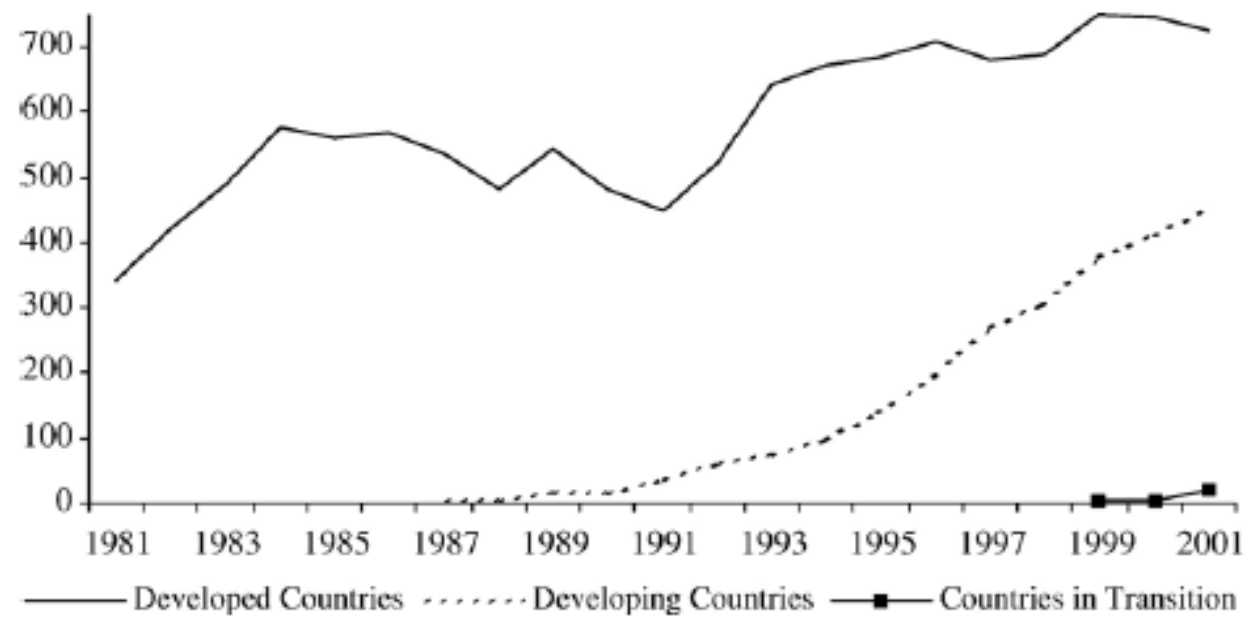

Source: Zanardi (2006, figure 3) 
Table 1 - Pooled OLS and fixed country-pair effects estimates of antidumping initiation and other trade friction effects on bilateral exports (1948-2001)

\begin{tabular}{|c|c|c|c|c|c|c|c|c|}
\hline \multirow{3}{*}{ Trade friction determinants of normalized bilateral exports } & \multicolumn{4}{|c|}{ Ignoring multilateral resistance (untransformed trade frictions) } & \multicolumn{4}{|c|}{ Accounting for multilateral resistance (transformed trade frictions) } \\
\hline & \multicolumn{2}{|c|}{$\begin{array}{c}\text { Model A } \\
\text { Pooled OLS }\end{array}$} & \multicolumn{2}{|c|}{$\begin{array}{c}\text { Model B } \\
\text { Fixed country-pair effects }\end{array}$} & \multicolumn{2}{|c|}{$\begin{array}{c}\text { Model C } \\
\text { Pooled OLS }\end{array}$} & \multicolumn{2}{|c|}{$\begin{array}{c}\text { Model D } \\
\text { Fixed country-pair effects }\end{array}$} \\
\hline & Coef. & t-statistic & Coef. & t-statistic & Coef. & t-statistic & Coef. & t-statistic \\
\hline \multicolumn{9}{|l|}{ Antidunmping variables: } \\
\hline$A D_{i j t}$ & -0.076 & -2.07 ** & -0.068 & $-2.44 * *$ & -0.112 & $-2.90 * \star \star$ & -0.073 & -2.53 ** \\
\hline$C A D_{i j t}$ & 0.002 & 0.75 & 0.005 & 1.62 & 0.001 & 0.26 & 0.004 & 1.43 \\
\hline \multicolumn{9}{|l|}{ Other trade frictions: } \\
\hline $\mathrm{NCU}_{\mathrm{ijt}}$ & -0.389 & $-4.90 * \star \star$ & -0.007 & -0.08 & -0.352 & $-4.21 * \star *$ & -0.014 & -0.14 \\
\hline $\mathrm{NFTA}_{\mathrm{ijt}}$ & 0.158 & $2.68 * * *$ & -0.107 & -1.79 * & 0.097 & 1.47 & -0.227 & $-3.24 * \star \star$ \\
\hline In DIST & -0.054 & $-8.05 * \star \star$ & - & - & -0.010 & -1.21 & - & - \\
\hline $\mathrm{NBORD}_{\mathrm{ij}}$ & 0.564 & 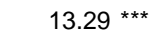 & - & - & 0.495 & $11.44^{\star \star \star}$ & - & - \\
\hline $\mathrm{NLANG}_{\mathrm{ij}}$ & 0.043 & 3.23 *** & - & - & -0.011 & -0.69 & - & - \\
\hline Observations & 294356 & & 294356 & & 294356 & & 294356 & \\
\hline Country-pairs & 21450 & & 21450 & & 19458 & & 19458 & \\
\hline Joint signif. of all regressors ( $p$-value of F-statistic) & 0.000 & & 0.000 & & 0.000 & & 0.000 & \\
\hline Joint signif. of multilat. resistance ( $p$-value of F-statistic) & - & & - & & 0.084 & & 0.000 & \\
\hline Hauman test ( $p$-value of $)^{2}$-statistic) & - & & 0.000 & & 0.000 & & 0.000 & \\
\hline Fixed country-pair effects (p-value of F-statistic) & - & & 0.000 & & - & & 0.000 & \\
\hline Fixed time effects ( $p$-value of F-statistic) & 0.000 & & 0.000 & & 0.924 & & 0.000 & \\
\hline
\end{tabular}


Table 2 - Sensitivity analysis of the antidumping effect on normalized exports (reference is Model D in Table 1)

Accounting for multilateral resistance (transformed trade frictions as in Model D of Table 1)

\begin{tabular}{|c|c|c|c|c|}
\hline \multirow[t]{2}{*}{ Type of model } & \multicolumn{2}{|c|}{ Parameter of $A D_{i j t}$} & \multicolumn{2}{|c|}{ Parameter of $C A D_{i j t}$} \\
\hline & Coef. & t-statistic $\left.{ }^{i}\right)$ & Coef. & t-statistic ${ }^{i}$ \\
\hline Reference: Model D in Table 1 & -0.073 & $-2.53^{* *}$ & 0.004 & 1.43 \\
\hline \multicolumn{5}{|l|}{ Sensitivity analyses: } \\
\hline (i) Including further time-variant trade frictions ${ }^{a}$ ) & -0.075 & $-2.61 * * *$ & 0.005 & 1.69 * \\
\hline (ii) As in (i) plus lagged antidumping measures ${ }^{\text {b) }}$ & -0.133 & $6.74 * \star \star$ & 0.011 & $4.31 * *$ \\
\hline (iii) As in (ii) plus twice lagged antidumping measures ${ }^{c}$ & -0.131 & $3.23 * *$ & 0.015 & $3.85 * *$ \\
\hline (iv) As in (iii) plus AD and CAD of exporter ${ }^{\text {d) }}$ & -0.134 & $3.79 \star \star$ & 0.013 & $2.93 * \star$ \\
\hline (v) As in (iv) but accounting for systematically missing trade flows ${ }^{\mathrm{e})}$ & -0.135 & $10.25 * *$ & 0.013 & 8.88 ** \\
\hline (vi) As in (iv) but using levels (incl. zeros) rather than the log of exports in a poisson QML model ${ }^{\text {f) }}$ & -0.212 & 4.65 * & 0.010 & 1.41 \\
\hline (vii) As in (iv) but using impositions of AD measures instead of investigations ${ }^{g}$ ) & -0.107 & 2.34 * & 0.002 & 0.13 \\
\hline (viii) As in (iv) but using GDP-weighted rather than unweighted averages for third-country effects ${ }^{\text {n) }}$ & -0.046 & -1.67 * & 0.017 & $6.28 * * *$ \\
\hline
\end{tabular}

All models include fixed country-pair effects and fixed time effects. ${ }^{* * *}$, ${ }^{* *}$, and * indicate significance levels of 1,5 , and 10 percent, respectively. - a) Beyond the timevariant trade frictions of Model D in Table 1, the specification icludes the following covariates: absence of WTO membership for one of the two countries; absence of WTO membership for both countries; absence of currency union membership; absence of currency peg membership; absence of currency band membership; absence of preferential (other than customs union of free trade area) membership. These variables are jointly significant at one percent. - b) Beyond the variables in specification (i) in this table, we include $A D_{i \mathrm{j}, \mathrm{t}-1}$ and $C A D_{\mathrm{i}, \mathrm{t}-\mathrm{-}-\mathrm{T}}$. These variables are jointly significant at five percent. The above coefficients are the accumulated ones (i.e., of $A D_{\mathrm{ijt}}$ and $A D_{\mathrm{ij}, \mathrm{t}-\mathrm{1}}$ together, and similarly for $C A D_{i j t}$ ). - c) Beyond the variables in specification (ii) in this table, we include $A D_{i, t,-2}$ and $C A D_{i, j,-2}$. These variables are jointly significant at five percent. The above coefficients are the accumulated ones (i.e., of $A D_{i j t}, A D_{i j, t-1}$, and $A D_{i j, t-2}$ together, and similarly for $C A D_{i j t}$ ). - d) Beyond the variables in specification (iii) in this table, we include the exporter's $A D_{\text {jit }}$ and $C A D_{\text {jit. }}$. These variables are jointly significant at one percent. - e) We apply Wooldridge's (1995) sample selection estimator for panel data, following the Mundlak-Chamberlain device of modelling the fixed effects by the means of the right-hand-side variables. We estimate annual selection models using the following determinants of the indicator for non-missing/non-zero exports: all variables as in specification (iv) in this table; the means of these variables; time-invariant geographical determinants such as common language, adjacency, log distance, log area of exporter plus importer, location on a common continent, and their demeaned counterparts to account for multilateral resistance as in equation (12). There is a vector of inverse Mill's ratios, one for each year. The test for sample selection relies on a model with a single Mill's ratio being made up of the annual ones (as suggested by Wooldridge, 1995). The test statistic of the latter is significant at one percent. - f) This model follows the suggestion of Tenreyro and Santos Silva (2006) by using a quasi-maximum likelihood Poisson model with robust standard errors. We follow the Mundlak device and additionally include country-pair means of all variables in the model to account for the panel nature of the data. Since zero trade flows are not wiped out by the logarithmic transformation, here, we cover 882,451 observations in this case. The model is nowWhile the point estimate in this model turns out to be larger than that in (iv), the two confidence intervals overlap enough so that the parameters for AD and CAD are not significantly different between (iv) and (vi). - $\mathrm{g}$ ) The data are provided by Chad Bown and available only from 1980 onwards. The total number of observations is 85,052 and there are 9,744 country-pairs. Other than using impositions rather than investigations, the estimated specification is the same as that in (iv) in this table. - h) See Baier and Bergstrand (2006) for this alternative approximation of the model by Anderson and van Wincoop (2003). The exporter's antidumping investigations are jointly significant in this model. - i) The figures for specifications (ii)-(vii) are F-statistics rather than t-statistcs. 
Table 3A - Further results ("Global chilling effect" specifications)

Case 1: Using the sum of antidumping investigations of country j against all countries in year $t$ in addition to the dyadby-year specific ones (in the spirit of Vandenbussche and Zanardi): ${ }^{\text {a) }}$

Variable

Coef. t-statistic

Sum of all contemporaneous investigations of country $\mathrm{j}$ in year $\mathrm{t}$

$0.090 \quad 0.90$

Case 2: Using the sum of antidumping impositions of country $\mathrm{j}$ against all countries in year $\mathrm{t}$ in addition to the dyad-byyear specific ones (in the spirit of Vandenbussche and Zanardi): ${ }^{a)}$

Variable

Coef. t-statistic

Sum of all contemporaneous impositions of country $\mathrm{j}$ in year $\mathrm{t}$

$-0.046$

$-0.32$

Case 3: Using the sum of antidumping investigations and that of impositions of country j against all countries in year $t$ in addition to the dyad-by-year specific ones (in the spirit of Vandenbussche and Zanardi): ${ }^{\text {a) }}$ Variable

Sum of all contemporaneous investigations of country $\mathrm{j}$ in year $\mathrm{t}$

Coef.

t-statistic

Sum of all contemporaneous impositions of country $j$ in year $t$

$-0.160$

$-1.12$

All models include fixed country-pair effects and fixed time effects. $* * \star * *$, and * indicate significance levels of 1,5 , and 10 percent, respectively. - a) The sum of antidumping investigations and/or impositions enter(s) insignificantly while the dyad-per-time-specific effects of $A D$ investigations and impositions remain significant. 
Table 3B - Further results continued (retaliation specifications)

Case 4: Using the specification as in (iii) of Table 2 plus a retaliation dummy that is unity if the exporter used $A D$ investigations against the importer in year t or any other year before:

\begin{tabular}{lrc} 
Variable & Coef. & t-statistic \\
\hline Retaliation dummy $y_{\mathrm{ijt}}$ & 0.204 & 1.27 \\
$A D_{\mathrm{ijt}}$ & -0.139 & 3.57 ** \\
$C A D_{\mathrm{ijt}}$ & 0.014 & $3.21 * \star$ \\
\hline
\end{tabular}

Case 5: Using the specification as in (iii) of the Table 2 plus a retaliation dummy that is unity if the exporter used $A D$ investigations against the importer in year $t$ or any other year before interacted with the number of $A D$ investigations: $^{\text {a) }}$

\begin{tabular}{lcc} 
Variable & Coef. & t-statistic \\
\hline Retaliation dummy & 0.040 & 0.67 \\
$A D_{i j t}$ & -0.139 & 3.36 ** \\
$C A D_{i j t}$ & 0.014 & $3.56 * *$ \\
\hline
\end{tabular}

Case 6: Using the specification as in (iv) of the Table 2 plus a retaliation dummy that is unity if the exporter used $A D$ investigations against the importer in year t or any other year before:

\begin{tabular}{lrc} 
Variable & Coef. & t-statistic \\
\hline Retaliation dummy & 0.026 & 0.16 \\
$A D_{i j t}$ & -0.135 & $3.36 * *$ \\
$C A D_{i j t}$ & 0.013 & $2.79 * *$ \\
\hline \hline
\end{tabular}

Case 7: Using the specification as in (iv) of the Table 2 plus a retaliation dummy that is unity if the exporter used $A D$ investigations against the importer in year $t$ or any other year before interacted with the number of $A D$ investigations: $^{\text {a) }}$

Variable

\begin{tabular}{lrc} 
Variable & Coef. & t-statistic \\
\hline Retaliation dummy & -0.19 \\
$\mathrm{AD}_{\mathrm{ijt}}$ & -0.011 & -011 \\
$\mathrm{CAD}$ & -0.132 & $3.01{ }^{* *}$ \\
\hline
\end{tabular}

Case 8: Using the specification as in (iv) of Table 2 plus 3 dummies: AD-law adoption of exporter; AD-law adoption of importer and the interactive term of the two. The dummies are set at 1 in any year of AD-law adoption and thereafter:

\begin{tabular}{|c|c|c|}
\hline Variable & Coef. & t-statistic \\
\hline Exporter's AD-law dummy & 14.743 & $4.5^{\star \star \star}$ \\
\hline Importer's AD-law dummy & -7.422 & -2.26 ** \\
\hline Interaction effect of exporter and importer AD-law dummy (both apply the law) & 0.023 & 0.72 \\
\hline$A D_{i j t}$ & -0.135 & 3.43 ** \\
\hline$C A D_{i j t}$ & 0.013 & 2.95 ** \\
\hline
\end{tabular}

All models include fixed country-pair effects and fixed time effects. ${ }^{* \star},{ }^{\star *}$, and * indicate significance levels of 1,5 , and 10 percent, respectively. - a) Here, the exporter's AD investigations are included as well and they enter significantly at 1 percent. Hence, the exporter's investigations matter, but not in a way that is interrelated with the importer's investigations as presumed in the retaliation literature. 
Table 4 - Quantifying the antidumping initiation effect on export volume (Percentage point changes of normalized exports from 1960 to 2000)

\begin{tabular}{lrr}
\hline Effect on exports of all countries into & Total effect & $\begin{array}{r}\text { Effect due to multi- } \\
\text { lateral resistance }\end{array}$ \\
\hline average country-pair in the sample & -0.119 & -0.024 \\
average country-pair with violating importer in the sample & -1.597 & -0.575 \\
average country-pair with non-violating importer in the sample & 0.035 & 0.035 \\
\hline
\end{tabular}
The reported effects are trade-weighted averages. 
Table 5 - Descriptive statistics

\begin{tabular}{|c|c|c|c|c|}
\hline \multirow[t]{2}{*}{ Variables } & \multicolumn{2}{|c|}{ Untransformed } & \multicolumn{2}{|c|}{$\begin{array}{c}\text { Demeaned as in Baier and } \\
\text { Bergstrand (2006) }\end{array}$} \\
\hline & Mean & Std. dev. & Mean & Std. dev. \\
\hline \multicolumn{5}{|l|}{ Antidumping investigations (AD) } \\
\hline contemporaneous $\left(A D_{i j t}\right)$ & 0.0067 & 0.1515 & 0.0002 & 0.1424 \\
\hline once lagged $\left(A D_{i j, t-1}\right)$ & 0.0063 & 0.1480 & 0.0003 & 0.1392 \\
\hline twice lagged $\left(A D_{i j, t-2}\right)$ & 0.0059 & 0.1418 & 0.0003 & 0.1336 \\
\hline \multicolumn{5}{|l|}{ Cumulative antidumping investigations } \\
\hline contemporaneous $\left(\mathrm{CAD}_{\mathrm{ijt}}\right)$ & 0.0577 & 2.1188 & 0.0076 & 2.0497 \\
\hline once lagged $\left(C A D_{i j, t-1}\right)$ & 0.0522 & 2.0465 & 0.0073 & 1.9812 \\
\hline twice lagged $\left(C A D_{i j}, t-2\right)$ & 0.0490 & 2.0416 & 0.0076 & 1.9798 \\
\hline \multicolumn{5}{|l|}{ Absence of regional trade agreements } \\
\hline customs unions $\left(\mathrm{CU}_{\mathrm{ijt}}\right)$ & 0.9956 & 0.0664 & 0.0007 & 0.0633 \\
\hline free trade areas $\left(\mathrm{FTA}_{\mathrm{ijt}}\right)$ & 0.9918 & 0.0902 & 0.0003 & 0.0799 \\
\hline other preferential trade agreements $\left(\mathrm{PTA}_{\mathrm{ijt}}\right)$ & 0.9836 & 0.1272 & -0.0004 & 0.1081 \\
\hline \multicolumn{5}{|l|}{ WTO non-membership of } \\
\hline one country in a pair & 0.4315 & 0.4953 & -0.0004 & 0.4377 \\
\hline both countries in a pair & 0.3460 & 0.4757 & 0.0001 & 0.2187 \\
\hline \multicolumn{5}{|l|}{ Absence of currency arrangements } \\
\hline currency unions & 0.9910 & 0.0947 & 0.0001 & 0.0356 \\
\hline currency pegs & 0.9628 & 0.1892 & -0.0011 & 0.1665 \\
\hline cureny bands & 0.9926 & 0.0856 & -0.0002 & 0.0791 \\
\hline \multicolumn{5}{|l|}{ Geographical and cultural variables } \\
\hline log bilateral distance (In DIST & 8.7524 & 0.7796 & -0.0053 & 0.6690 \\
\hline absence of a common border & 0.9852 & 0.1206 & 0.0013 & 0.1193 \\
\hline absence of a common language & 0.8423 & 0.3645 & -0.0025 & 0.3114 \\
\hline
\end{tabular}

